\title{
DAMPAK KETERBUKAAN ORANG TUA TERHADAP PRESTASI ANAK PENDERITA AUTIS DI SEKOLAH LUAR BIASA C RAJAWALI DAN KLINIK BUAH HATIKU MAKASSAR
}

\author{
Srinova \\ sttjaffraymakassar@yahoo.co.id \\ Ivan Th.J.Weismann
}

\begin{abstract}
ABSTRAK
Srinova, Dampak keterbukaan orang tua terhadap Prestasi anak penderita autis di sekolah luar biasa c rajawali dan klinik buah hatiku makassar.

Tujuan penulisan pada karya ilmiah ini adalah untuk menganalisis pengaruh keterbukaan orang tua, berupa penerimaan dan bahasa kasih terhadap prestasi anak autis di Sekolah Luar Biasa C Rajawali dan Klinik Buah.Hatiku.Makassar.

Adapun metode penelitian yang digunakan dalam penulisan karya ilmiah ini untuk mendapatkan data yang diperlukan, adalah: Pertama, angket dikelola secara kuantitatif untuk mengetahui hubungan antara penerimaan orang tua dan bahasa kasih yang ditunjukkan oleh orang tua terhadap prestasi anak penderita autis. Populasinya adalah semua anak autis di Sekolah Luar Biasa C Rajawali Makassar dan Klinik Buah Hatiku Makassar, yang berjumlah 25 orang. Sampel dalam tulisan ini adalah anak autis di Sekolah Luar Biasa C Rajawali Makassar sebanyak 6 orang dan anak autis di Klinik Buah Hatiku Makassar sebanyak 19 orang. Teknik analisis data yang digunakan adalah analisis regresi linear dengan menggunakan program SPSS 17. Kedua, metode library research atau pengumpulan data melalui studi kepustakaan, yakni penulis mencari dan membaca beberapa buku yang berkaitan dengan judul karya ilmiah yang akan penulis bahas. Ketiga, metode wawancara dan observasi. Dalam metode ini, penulis akan memperoleh data-data dari berbagai pihak, khususnya yang terlibat langsung dalam menangani anak autis.

Hasil yang diperoleh dari penelitian ini adalah: Pertama, Penerimaan orang tua berpengaruh terhadap prestasi anak autis. Kedua, bahasa kasih yang ditunjukkan oleh orang tua berpengaruh terhadap prestasi anak autis.
\end{abstract}

Kata Kunci : Keterbukaan Orang Tua, Prestasi Anak, Penderita Autis 


\section{PENDAHULUAN}

\section{Latar Belakang Masalah}

Anak merupakan anugerah yang diberikan oleh Tuhan kepada setiap keluarga. Kehadiran seorang anak merupakan dambaan setiap keluarga. Tidak sedikit juga dari orang tua yang tidak menghendaki kehadiran seorang anak. Hal ini disebabkan oleh banyak faktor, diantaranya memiliki anak di luar nikah, terlalu banyak anak atau cacat yang dialami oleh anak, salah satu contoh diantaranya yaitu anak yang menderita autis. Orang tua yang memiliki anak autis sering dibayangi terus menerus oleh pertanyaan: kenapa harus anak saya? Banyak orang tua yang tidak terima anaknya menderita autis. Autisme terjadi pada 5 dari setiap 10.000 kelahiran, dimana jumlah penderita laki-laki empat kali lebih besar dibandingkan penderita wanita. Meskipun demikian, bila kaum wanita mengalaminya, maka penderitaannya akan lebih parah dibandingkan kaum pria. ${ }^{1}$

Beberapa dari orang tua yang memiliki anak yang terdiagnosa autis, terus mencari informasi sebanyak-banyaknya tentang pertanyaan mengapa anak saya autis?, tetapi mereka tetap tidak mau menerima kenyataan anaknya yang terkena autis. Setiap orang tua selalu mengharapkan agar buah hatinya dapat tumbuh dan berkembang dengan normal dan sehat. Orang tua seharusnya bisa menerima anak yang telah dilahirkan ke dunia apapun kondisi anaknya dan berusaha melawan rasa cemas dan khawatir yang selalu menghantui.

Tidak sedikit juga dari orang tua yang malu untuk mengakui bahkan malu untuk memperkenalkan anak mereka yang mengalami autis kepada orang lain. Bagi sebagian mereka, memiliki anak autis merupakan suatu hal yang sangat memalukan. Oleh karena itu, banyak cara yang mereka lakukan agar orang lain tidak mengetahui hal tersebut. Apakah dengan mengurungnya di rumah atau berpura-pura tidak tahu kalau anak mereka menderita autis. Bahkan ada orang tua yang mengisolasikan diri karena merasa bahwa orang lain menutup diri terhadap mereka karena mereka memiliki anak yang menderita autis. ${ }^{2}$ Orang tua tidak menyadari bahwa dengan cara mereka yang seperti ini, akan membawa dampak yang buruk bagi perkembangan sang anak.

Orang tua seharusnya tetap memberikan cinta dan kasih sayang seperti layaknya pada anak normal. Sebagaimana tugas orang tua yang tertulis di dalam Efesus 6:4 yang menyatakan "dan kamu, bapa-bapa, janganlah bangkitkan amarah di dalam hati anak-anakmu, tetapi

\footnotetext{
${ }^{\mathrm{l}}$ Mirza Maulana, Anak Autis : Mendidik Anak Autis Dan Gangguan Mental Lain Menuju Anak Cerdas Dan Sehat (Jogjakarta: Kata Hati, 2007), 11.

${ }^{2}$ Ny. Nurmala, Prof Hembing Telah Sembuhkan Anakku Dari Autism (Jakarta, 2002), 54
} 
didiklah mereka di dalam ajaran nasihat Tuhan.” Dan di dalam Amsal 29:17 yang menyatakan "didiklah anakmu, maka ia akan memberikan ketentraman kepadamu, dan mendatangkan sukacita kepadamu". I Timotius 5:8 menyatakan, "tetapi jika ada seorang yang tidak memeliharakan sanak saudaranya, apalagi seisi rumahnya, orang itu murtad dan lebih buruk dari orang yang tidak beriman". Orang tua adalah pembimbing dan penolong yang paling baik dan berdedikasi tinggi. Dan yang dapat menyelami dunia anak adalah orangtuanya sendiri. ${ }^{3}$

Anak autis hanyalah anak yang punya kondisi otak berbeda dengan anak lainnya. Perlu disadari bahwa anak autis adalah anak spesial karena memiliki kemampuan yang berbeda dengan anak umumnya, oleh karena itu penanganannya pun harus spesial. Orang tua boleh saja bersedih jika anaknya mengalami autis, tapi jangan terlalu lama. Karena anak autis punya kelebihan istimewa yang bisa membuatnya mandiri. Orang tua dari anak autis harus memiliki kesabaran yang tinggi, mau mencari tahu segala macam informasi serta mau melakukan sesuatu agar anaknya bisa tumbuh layaknya anak normal, yang memiliki mental dan prestasi yang bisa dibanggakan. Menurut Billy Graham, kesabaran adalah suatu kemampuan untuk menampung berbagai tegangan dan tekanan hidup tanpa keluhan dan tidak merasa terganggu oleh berbagai rintangan, penangguhan, atau kegagalan. ${ }^{4}$

Orang tua harus memberikan kasih sayang yang tulus kepada anaknya. Karena ini sangat memegang peranan penting dalam perkembangan anak. Kasih sayang dapat membimbing ibu untuk memahami sampai seberapa jauh kebutuhan fundamental anak dapat dan boleh dipenuhi dan pada batas-batas mana anak harus dibiarkan menentukan sendiri respon-responnya untuk memenuhi kebutuhannya, sehingga proses belajarnya tidak terhambat dan membantu dalam pembentukan egonya. ${ }^{5}$

Hal yang tidak boleh dimiliki oleh orang tua dalam mengasuh anak yang menderita autis yaitu marah, mengeluh dan mengabaikan. Orang tua harus senantiasa bersyukur atas semua hal yang terjadi. Tidak mudah untuk bersyukur atas setiap hal buruk yang terjadi. Jangankan hal buruk, hidup dengan normal saja, orang jarang sekali bersyukur.

\footnotetext{
${ }^{3}$ Mirza Maulana, Anak Autis : Mendidik Anak Autis Dan Gangguan Mental Lain Menuju Anak Cerdas Dan Sehat (Jogjakarta: Kata Hati, 2007), 68

${ }^{4}$ Billy Graham, Buku Pegangan Pelayanan, (Persekutuan Pembaca Alkitab, 1988), 114

${ }^{5}$ Singgih dan Yulia Gunarsa, Psikologi Perkembangan Anak Dan Remaja (Jakarta:Gunung Mulia, 2010), 57-58
} 
Orang tua harus yakin bahwa, selalu ada hikmah tersembunyi ketika sebuah keluarga dianugerahi anak berkebutuhan khusus (autis).

Dengan melihat kenyataan tersebut di atas, penulis merasa terdorong untuk mendekarya ilmiahkan hal tersebut dalam sebuah karya ilmiah dengan judul: "DAMPAK KETERBUKAAN ORANG TUA TERHADAP PRESTASI ANAK PENDERITA AUTIS DI SEKOLAH LUAR BIASA C RAJAWALI DAN KLINIK BUAH HATIKU MAKASSAR".

\section{Pokok Masalah}

Beranjak dari latar belakang di atas, maka yang menjadi titik tolak permasalahan adalah sejauh mana dampak keterbukaan orang tua, berupa penerimaan dan bahasa kasih terhadap prestasi anak autis di Sekolah Luar Biasa C Rajawali dan Klinik Buah Hatiku.Makassar.

\section{Tujuan Penulisan}

Tujuan penulisan yang dilakukan sehubungan dengan karya ilmiah ini adalah untuk menganalisis pengaruh keterbukaan orang tua, berupa penerimaan dan bahasa kasih terhadap prestasi anak autis di Sekolah Luar Biasa C Rajawali dan Klinik Buah.Hatiku.Makassar.

\section{Manfaat Penulisan}

Pertama, untuk memenuhi salah satu persyaratan akademik untuk memperoleh gelar kesarjanaan pada program Sl Pendidikan Agama Kristen pada Sekolah Tinggi Theologia Jaffray Makassar.

Kedua, diharapkan dapat menjadi petunjuk dan pedoman bagi orang tua khususnya dalam menangani anaknya yang terdiagnosa autis agar anaknya yang autis juga bisa berprestasi dan tidak terisolasi dari anak normal lainnya.

Ketiga, menambah wawasan pembaca terhadap gangguan perkembangan, yaitu autis yang terjadi pada anak.

\section{Metode Penelitian}

Adapun metode penelitian yang digunakan dalam penulisan karya ilmiah ini untuk mendapatkan data yang diperlukan, adalah :

Pertama, angket dikelola secara kuantitatif untuk mengetahui hubungan antara penerimaan orang tua dan bahasa kasih yang ditunjukkan oleh orang tua terhadap prestasi anak penderita autis. Populasinya adalah semua anak autis di Sekolah Luar Biasa C Rajawali Makassar dan Klinik Buah Hatiku Makassar, yang berjumlah 25 orang. Sampel dalam tulisan ini adalah anak autis di Sekolah Luar Biasa C Rajawali Makassar sebanyak 6 orang dan anak autis di Klinik Buah Hatiku Makassar sebanyak 19 orang. Teknik analisis data yang 
digunakan adalah analisis regresi linear dengan menggunakan program SPSS 17.

Kedua, metode library research atau pengumpulan data melalui studi kepustakaan, yakni penulis mencari dan membaca beberapa buku yang berkaitan dengan judul karya ilmiah yang akan penulis bahas.

Ketiga, metode wawancara dan observasi. Dalam metode ini, penulis akan memperoleh data-data dari berbagai pihak, khususnya yang terlibat langsung dalam menangani anak autis.

\section{Batasan Penulisan}

Dalam penulisan karya ilmiah ini, penulis membatasi hanya pada keterbukaan orang tua, berupa penerimaan orang tua terhadap keberadaan anaknya yang autis dan bahasa kasih yang ditunjukkan oleh orang tua terhadap prestasi anak autis. Penulis membatasi penelitian kepada anak yang terdiagnosa autis yang berumur 6-13 tahun.

\section{METODOLOGI PENELITIAN}

\section{Gambaran Umum}

\section{Sekolah Luar Biasa C Rajawali}

Sekolah Luar Biasa C Rajawali Makassar berdiri tahun 1978. Sekolah yang terletak di jalan Arief Rate no 2 ini dikelola oleh Yayasan Joseph Yeemye yang berpusat di Makassar. Sampai dengan Mei 201l, siswanya berjumlah 57 orang sudah termasuk di dalamnya TK, SD, SMP dan SMA. Sejak berdiri sampai sekarang sekolah dipimpin langsung oleh yayasan penyelenggara sekolah serta sudah ada delapan kepala sekolah yang memimpin sekolah ini. Kepala sekolah yang memimpin sekarang adalah Sr. Benedicta Bororing JMJ, S. Pd.

Sekolah Luar Biasa C Rajawali memiliki siswa yang terdiri dari bermacam-macam suku dan etnis serta dengan keadaan sosial ekonomi masyarakat kota pada umumnya, mulai dari warga masyarakat yang ekonomi lemah hingga menengah ke atas. Dengan kata lain Sekolah Luar Biasa C Rajawali hadir di antara masyarakat kota Makassar dengan corak sosial ekonomi yang heterogen. Disisi lain sebagai salah satu lembaga pendidikan, Sekolah Luar Biasa C Rajawali senantiasa berupaya menjembatani dan merekatkan kondisi sosial ekonomi yang berbeda dalam memberikan kesempatan untuk mendapatkan pendidikan yang layak dan sama bagi setiap anak usia sekolah di kota Makassar dan sekitarnya. 


\section{Klinik Buah Hatiku}

Klinik Buah Hatiku adalah merupakan pusat terapi terpadu autisme serta gangguan perkembangan lainnya. Klinik ini terletak di jl. Gunung Latimojong no 129C, berdekatan dengan Metro School dan sudah berdiri selama sebelas tahun. Pendirinya adalah Ibu Sinta dan Ibu Jaqline. Awal berdirinya tempat terapi ini terinspirasi dari pendirinya yang memiliki anak yang menderita autis. Sampai dengan sekarang jumlah anak yang terdaftar mengikuti jadwal terapi yaitu berjumlah lima puluh orang.

\section{Jenis Penelitian}

Jenis penelitian yang digunakan dalam penelitian ini adalah bersifat kuantitatif mengenai pengaruh keterbukaan orang tua berupa penerimaan dan bahasa kasih yang ditunjukkan oleh orang tua terhadap prestasi anak autis.

\section{Populasi dan sampel Populasi}

Populasi adalah seluruh penduduk yang dimaksudkan untuk diteliti". Setiap penelitian ilmiah tentunya mempunyai objek penelitian, baik berupa benda maupun makhluk hidup lainnya. Populasi sangat berperan penting dalam penelitian, karena dari populasi tersebut, diharapkan sejumlah data dan informasi yang dibutuhkan dapat menjadi landasan dalam pembahasan penelitian.

Berdasarkan defenisi populasi di atas, maka dapat disimpulkan bahwa populasi adalah keseluruhan makhluk hidup dan benda-benda yang ada di lokasi untuk diteliti sebagai sasaran penelitian. Sehubungan dengan itu, maka penulis memfokuskan pada semua anak autis di Sekolah Luar Biasa C Rajawali Makassar dan Klinik Buah Hatiku, yang berjumlah 25 orang.

\section{Sampel}

Sampel adalah bagian dari populasi. Sampel adalah jumlah penduduk yang jumlahnya kurang dari populasi. Jadi sampel adalah bagian dari populasi atau yang mewakili secara keseluruhan dari populasi, maka penelitian yang dilakukan terhadap sampel itu pada umumnya bertujuan untuk menarik kesimpulan tentang populasi".

Berdasarkan pengertian di atas, maka yang menjadi sampel dalam tulisan ini adalah anak autis di Sekolah Luar Biasa C Rajawali Makassar sebanyak 6 orang dan anak autis di Klinik Buah Hatiku sebanyak 19 orang.

\footnotetext{
${ }^{6}$ Sutrisno Hadi, Statistik, (Yogyakarta: FIP-IKIP, 1975), 3

${ }^{7}$ Ibid
} 


\section{Teknik Pengumpulan Data}

\section{Pembuatan Kuesioner}

Dalam pembuatan kuesioner ini, penulis memakai kuesioner langsung. "Suatu kuesioner disebut langsung jika daftar pertanyaan dikirim kepada orang yang meminta pendapatnya atau diminta untuk menceritakan tentang keadaan dirinya".

\section{Bentuk Pertanyaan}

Bentuk pertanyaan yang dipakai dalam penelitian ini berbentuk pertanyaan tertutup (multiple choice), yaitu pertanyaan yang variasi jawabannya adalah ditentukan dan disusun terlebih dahulu sehingga responden tidak mempunyai kebebasan untuk memberikan jawaban kecuali pada jawaban yang sudah ditentukan. ${ }^{9}$ Pertanyaanpertanyaannya adalah mengenai penerimaan orang tua, bahasa kasih yang ditunjukkan oleh orang tua dan prestasi anak autis. Adapun pertanyaan terlampir.

\section{Teknik Analisis Data}

Teknik analisis data yang digunakan adalah analisis regresi linear dengan menggunakan program SPSS 17. Yang dianalisis adalah hubungan keterbukaan orangtua berupa penerimaan dan bahasa kasih yang ditunjukkan oleh orangtua terhadap prestasi anak autis.

\section{ANALISIS HASIL PENELITIAN DAN PEMBAHASAN}

Dalam bab ini, penulis akan membahas hasil penelitian yang dilakukan oleh penulis melalui pembagian angket kepada orang tua anak yang terdiagnosa autis.

\section{Pengaruh Penerimaan Orang Tua Terhadap Prestasi Anak Autis}

Berikut ini adalah nama-nama responden yang diteliti. Peneliti memberikan angket kepada responden untuk kemudian diisi. Adapun data yang diperoleh dari hasil angket tentang penerimaan orang tua dan prestasi adalah berikut di bawah ini:

\footnotetext{
${ }^{8}$ Sutrisno Hadi, Metodologi Research Jilid 2, (Yogyakarta: Andi Soffet, 1990), 158

${ }^{9}$ Ibid, 160
} 
Tabel Skor Penerimaan Orang Tua Dan Prestasi

\begin{tabular}{|c|c|c|c|}
\hline No & Nama & Penerimaan Orang tua & Prestasi \\
\hline 1 & Elisabet & 12 & 43 \\
\hline 2 & Prima & 13 & 43 \\
\hline 3 & Sean & 12 & 40 \\
\hline 4 & Roihan & 14 & 32 \\
\hline 5 & Pander & 11 & 34 \\
\hline 6 & Jafier & 12 & 29 \\
\hline 7 & Henry & 12 & 42 \\
\hline 8 & Alifarqad & 12 & 32 \\
\hline 9 & Dirga & 12 & 36 \\
\hline 10 & Sy & 12 & 37 \\
\hline 11 & Ry & 11 & 32 \\
\hline 12 & BR & 12 & 34 \\
\hline 13 & Ag & 12 & 32 \\
\hline 14 & Aj & 14 & 42 \\
\hline 15 & As & 12 & 36 \\
\hline 16 & Gz & 14 & 32 \\
\hline 17 & Kn & 14 & 48 \\
\hline 18 & Ms & 12 & 39 \\
\hline 19 & Hl & 11 & 32 \\
\hline 20 & Mh & 14 & 48 \\
\hline 21 & Px & 14 & 48 \\
\hline 22 & Hr & 12 & 39 \\
\hline 23 & $\mathrm{Mp}$ & 13 & 40 \\
\hline 24 & $\mathrm{Mc}$ & 13 & 42 \\
\hline 25 & Dn & 12 & \\
\hline & & & 42 \\
\hline
\end{tabular}

Tabel Skor Rata-Rata Prestasi Dan Penerimaan Orang tua

\begin{tabular}{|c|c|c|}
\hline & Mean & N \\
\hline Prestasi & 38.16 & 25 \\
Penerimaan Orangtua & 12.48 & 25 \\
\hline
\end{tabular}


Tabel di atas menunjukkan rata-rata prestasi anak autis yaitu 38.16, rata-rata penerimaan orang tua adalah 12.48 dari 25 responden yang diteliti.

Tabel Korelasi Prestasi dan Penerimaan Orang Tua Correlations

\begin{tabular}{|ll|l|l|}
\hline & & Prestasi & $\begin{array}{l}\text { Penerimaan } \\
\text { Orangtua }\end{array}$ \\
\hline Pearson & Prestasi & 1.000 & .509 \\
Correlation & Penerimaan Orangtua & .509 & 1.000 \\
\hline Sig. (1-tailed) & Prestasi & & .005 \\
& Penerimaan Orangtua & .005 &. \\
\hline N & Prestasi & 25 & 25 \\
& Penerimaan Orangtua & 25 & 25 \\
\hline
\end{tabular}

Besar hubungan antar variabel prestasi dengan penerimaan orangtua koefisien korelasinya ialah 0.509. Hal ini menunjukkan hubungan yang sedang. Hubungan sangat erat jika koefisien korelasinya mendekati angka 1 . Arah hubungan yang positif menunjukkan semakin besar penerimaan orang tua akan membuat prestasi anak autis cenderung meningkat. Demikian pula sebaliknya, makin kecil penerimaan orang tua semakin kecil pula prestasi anak autis.

Tingkat signifikansi koefisien korelasi adalah 0.005. Oleh karena probabilitas jauh di bawah 0.05 , maka korelasi antara penerimaan orang tua dengan prestasi anak autis sangat nyata.

Berdasarkan isian angket, diperoleh data bahwa semakin besar penerimaan orang tua, akan berdampak kepada prestasi anak autis. Penerimaan orang tua diantaranya berupa: dapat menerima kenyataan, sikap dan perilaku serta menganggap anaknya yang autis sebagai anugerah yang diberikan oleh Tuhan. Kemudian mengasuh anaknya sendiri tanpa dibantu oleh baby sitter serta memberikan anaknya kepada professional autis untuk diterapi, memperhatikan jenis makanan dan minuman yang diberikan kepada anak. Penerimaan orang tua yang seperti ini akan menunjukkan prestasi yang nyata. Adapun prestasi yang ditunjukkan oleh anak autis diantaranya adalah anak autis menjadi tidak terlalu sensitif, bisa melakukan kontak mata dan senyum secara sosial, tidak kaku lagi terhadap orang lain, sudah tidak berteriak-teriak dan tidak membeo, tidak gampang marah (memiliki emosi yang stabil), tidak mudah menyakiti diri sendiri, sudah bisa bermain dengan temantemannya. 


\section{Tabel Persentasi}

\begin{tabular}{|c|c|c|c|c|}
\hline \multicolumn{5}{|c|}{ Model Summary $^{\mathrm{b}}$} \\
\hline Model & $\mathrm{R}$ & R Square & $\begin{array}{l}\text { Adjusted } \\
\text { Square }\end{array}$ & $\mathrm{R} \mid \begin{array}{l}\text { Std. Error of } \\
\text { the Estimate }\end{array}$ \\
\hline 1 & $.509^{a}$ & .259 & .226 & 4.954 \\
\hline
\end{tabular}

a. Predictors: (Constant), Penerimaan Orang tua

b. Dependent Variable: Prestasi

Angka R square adalah 0.259 dikali 100\% menjadi 25\%. Hal ini berarti $25 \%$ variabel prestasi ditentukan oleh variabel penerimaan orang tua. Sisanya yaitu $75 \%$ ditentukan oleh faktor lain. Walaupun penerimaan orang tua mempengaruhi hanya 25\% terhadap prestasi anak autis tetapi anak autis sangat memerlukan penerimaan dari orang tua.

Sangat disarankan bagi orang tua, ketika mereka memiliki anak yang terdiagnosa menderita autis agar dapat menerima kenyataan itu dengan tetap bersyukur karena bagaimanapun, itu adalah merupakan anugerah yang diberikan oleh Tuhan kepadanya, jadi harus dengan lapang dada menerima kenyataan tersebut. Serta dengan penuh kesabaran mengasuh anak dengan memperhatikan setiap detail perkembangan anak. Selalu memberikan yang terbaik bagi anak, seperti memperhatikan makanan dan minuman yang dianjurkan dan yang dilarang untuk dikonsumsi oleh anak dan memberikan anak kepada para professional autis untuk kemudian diterapi. Dengan melakukan hal ini dengan penuh ketekunan dan kesabaran, maka orang tua akan melihat bagaimana perubahan yang terjadi pada anaknya.

Contoh yang nyata bisa kita lihat pada diri Faisal Rahman (6 tahun), yang terdiagnosa menderita autis dengan gejala yang tampak berupa hiperaktif, tertawa-tawa sendiri, melambai-lambaikan tangan di depan mata, tantrum, kebiasaan meludah, keterbatasan bicara, dan sebagainya. Berikut ini adalah kesaksian dari orangtuanya:

Sebagai anak autis, sikap acuh merupakan perilaku yang menjadi ciri khasnya, selain keterbatasan kontak mata dan keterbatasan bicara. Seperti orang tua lainnya, kami pun sempat dibuatnya bingung tanpa tahu harus bagaimana mengatasi semua gangguan yang ada hingga akhirnya kami mendapatkan informasi tentang suatu tempat terapi. Dengan beberapa kali menjalani terapi, anak kami yang semula hiperaktif, kini sudah bisa bersikap tenang. Perilaku tantrum yang 
dulu adapun sudah jauh berkurang. Begitupun dengan kebiasaan meludah. Kemampuan berbicaranya juga sudah semakin bagus dari hari ke hari, meskipun masih terbatas, dan masih sulit untuk mengucapkan huruf R. Jika sebelumnya ia hanya terbatas mengucapkan sepatah dua patah kata, kini Faisal sudah bisa mengucapkan lebih banyak kata dan bisa merangkainya menjadi kalimat. Kemampuan bicaranya semakin berkembang. Ia sudah berinisiatif memulai pembicaraan, mau menyapa temannya misalnya dengan memanggil "Adik Ezra!", dan suatu ketika dengan spontan terlontar ucapan, "Mas Untung, tolong!"(Mas Untung adalah salah seorang yang membantu saat terapi air).

Sikap acuh yang dulu ada, berangsur-angsur hilang dan berganti dengan kepatuhan yang bagus. Ia kini jadi lebih mudah melakukan instruksi yang diberikan. Ia bahkan sudah menunjukkan sikap kemandirian. Untuk memakai baju, memakai sepatu, mengancingkan celana, dan keperluannya sendiri yang lain, sudah dapat ia kerjakan sendiri tanpa mau dibantu oleh kami.

Kontak matanya yang dulu sangat terbatas, kini sudah mau focus. Barangkali karena perbaikan tersebutlah anak kami kini lebih mudah memusatkan perhatian dan konsentrasinya, terutama untuk menjalankan aktivitas menggambar. Faktor imajinasi dalam gambarannya kami akui sangat bagus. Gambar yang dihasilkan oleh Faishal bukan hanya sekedar gambar yang biasa dibuat anak-anak. Gambar yang dibuatnya terlihat lebih hidup, misalnya jika ia menggambar rumah, ia bukan hanya akan membuat rumah sebagai objek, tetapi akan ada objek lain selain rumah itu sendiri, seperti pepohonan,antenna TV, pekarangan, dan sebagainya. Jika kami mengatakan kepadanya bahwa ada yang masih kurang dari gambarnya, iapun akan menambahkan objek lain pada gambar tersebut sesuai instruksi kami.

Sosialisasinya yang sudah bagus membuat anak kami memiliki kepatuhan yang bagus. Faishal juga sudah mahir bermain game yang menurut kami memiliki tingkat kesulitan yang relative tinggi untuk anak seusianya.

Dari berbagai perbaikan yang ada, kami juga mengakui masih ada gejala yang masih suka muncul, seperti menutup telinga atau melambai-lambaikan tangan di depan mata atau kadang-kadang suka tertawa sendiri. Akan tetapi, kami tetap berkeyakinan bahwa dengan kesabaran dan menjalani terapi secara berkelanjutan, semua itu akan segera teratasi. Jika Tuhan menghendaki, semoga di masa 
yang akan datang Faishal akan semakin mengalami perkembangan dan mampu mewujudkan cita-citanya. ${ }^{10}$

Berdasarkan kesaksian tersebut di atas, maka kita bisa melihat bagaimana pengaruh yang sangat nyata dari penerimaan orang tua terhadap prestasi anak autis. Orang tua yang memiliki kesabaran dalam mengasuh anaknya dan menghadapi semua kelakuan anaknya dengan penuh pengertian, bahkan berusaha mencari informasi demi kesembuhan anaknya dengan cara memberikan anaknya kepada profesional autis untuk diterapi akan memberikan dampak yang positif dalam diri anaknya. Perubahan-perubahan yang nyatapun kita bisa lihat dalam diri anak autis tersebut, diantaranya anak yang semula hiperaktif, kini sudah bisa bersikap tenang. Perilaku tantrum yang dulu adapun sudah jauh berkurang. Begitupun dengan kebiasaan meludah. Kemampuan berbicaranya juga sudah semakin bagus dari hari ke hari, meskipun masih terbatas, sikap acuh yang dulu ada, berangsur-angsur hilang dan berganti dengan kepatuhan yang bagus, sudah menunjukkan sikap kemandirian contohnya sudah bisa untuk memakai baju, memakai sepatu, dan mengancingkan celana sendiri. Kontak matanya yang dulu sangat terbatas, kini sudah mau fokus. Anakpun sudah bisa bersosialisasi.

Tabel Persamaan Regresi

\begin{tabular}{|l|l|}
\hline \multirow{2}{*}{ Model } & Unstandardized Coefficients \\
\cline { 2 - 2 } & $\mathrm{B}$ \\
\hline (Constant) & 2.594 \\
Penerimaan Orangtua & 2.850 \\
\hline
\end{tabular}

Tabel di atas mengambarkan persamaan regresi

$\mathrm{Y}=2.594+2.850 \mathrm{X}$

Di mana:

$\mathrm{Y}=$ Prestasi

$\mathrm{X}=$ Penerimaan orang tua

Konstanta sebesar 2.594 menyatakan bahwa jika tidak ada penerimaan orang tua maka prestasi anak autis adalah 2.594. koefisien regresi sebesar 2.850 menyatakan bahwa setiap penambahan 1 skor penerimaan orang tua akan meningkatkan prestasi sebesar 2.850 .

\footnotetext{
2002), 46

${ }^{10}$ Wahyu Rohman, Prof. Hembing telah Sembuhkan Anakku dari Autism (Jakarta,
} 


\section{Gambar Hubungan Penerimaan Orang Tua Dengan Prestasi}

Scatterplot

\section{Dependent Variable: Prestasi}

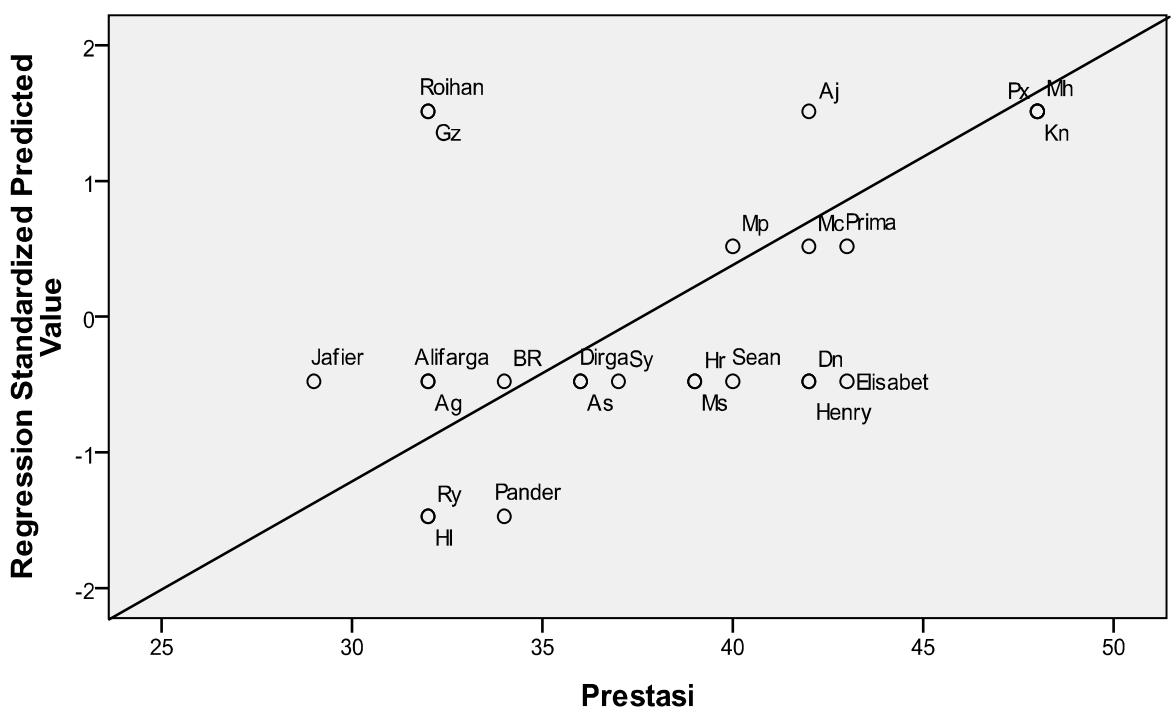

Terlihat bahwa sebaran data membentuk arah ke kanan atas, dan jika ditarik garis lurus akan didapat slope yang positif. Hal ini berarti ada hubungan yang positif antara prestasi dan penerimaan orang tua.

\section{Pengaruh Bahasa Kasih Terhadap Prestasi Anak Autis}

Berikut ini adalah nama-nama responden yang diteliti. Adapun data yang diperoleh dari hasil angket tentang bahasa kasih dan prestasi adalah berikut di bawah ini:

Tabel Skor Bahasa Kasih Dan Prestasi

\begin{tabular}{|l|l|l|l|}
\hline No & \multicolumn{1}{|c|}{ Nama } & Bahasa kasih & Prestasi \\
\hline 1 & Elisabet & 14 & 43 \\
\hline 2 & Prima & 14 & 43 \\
\hline 3 & Sean & 16 & 40 \\
\hline 4 & Roihan & 16 & 32 \\
\hline 5 & Pander & 12 & 34 \\
\hline 6 & Jafier & 13 & 29 \\
\hline 7 & Henry & 16 & 42 \\
\hline
\end{tabular}




\begin{tabular}{|l|l|l|l|}
8 & Alifarqad & 16 & 32 \\
\hline 9 & Dirga & 16 & 36 \\
\hline 10 & Sy & 16 & 37 \\
\hline 11 & Ry & 16 & 32 \\
\hline 12 & BR & 16 & 34 \\
\hline 13 & Ag & 14 & 32 \\
\hline 14 & Aj & 15 & 42 \\
\hline 15 & As & 16 & 36 \\
\hline 16 & Gz & 14 & 32 \\
\hline 17 & Kn & 16 & 48 \\
\hline 18 & Ms & 13 & 39 \\
\hline 19 & Hl & 13 & 32 \\
\hline 20 & Mh & 16 & 48 \\
\hline 21 & Px & 16 & 48 \\
\hline 22 & Hr & 15 & 39 \\
\hline 23 & Mp & 16 & 40 \\
\hline 24 & Mc & 15 & 42 \\
\hline 25 & Dn & 14 & 42 \\
\hline
\end{tabular}

Tabel Skor Rata-Rata Prestasi Dan Bahasa Kasih

\begin{tabular}{|l|l|l|}
\hline & Mean & N \\
\hline Prestasi & 38.16 & 25 \\
Bahasa Kasih & 14.96 & 25 \\
\hline
\end{tabular}

Tabel di atas menunjukkan rata-rata prestasi anak autis yaitu 38.16, rata-rata bahasa kasih adalah 14.96 dari 25 responden yang diteliti.

Table Korelasi Prestasi Dan Bahasa Kasih

Correlations

\begin{tabular}{|ll|l|l|}
\hline & & Prestasi & Bahasa Kasih \\
\hline Pearson & Prestasi & 1.000 & .285 \\
Correlation & Bahasa Kasih & .285 & 1.000 \\
\hline Sig. (1-tailed) & Prestasi & & .083 \\
& Bahasa Kasih & .083 &. \\
\hline N & Prestasi & 25 & 25 \\
& Bahasa Kasih & 25 & 25 \\
\hline
\end{tabular}


Besar hubungan antar variabel prestasi dengan bahasa kasih koefisien korelasinya ialah 0.285. Hal ini menunjukkan hubungan yang jauh. Hubungan sangat erat jika koefisien korelasinya mendekati angka 1. Arah hubungan yang positif menunjukkan semakin besar bahasa kasih yang ditunjukkan oleh orang tua akan membuat prestasi anak autis cenderung meningkat. Demikian pula sebaliknya, makin kecil bahasa kasih yang ditunjukkan orang tua semakin kecil pula prestasi anak autis. Walaupun hubungan tidak erat, tetapi bahasa kasih tetap dibutuhkan karena angka 0.285 adalah angka yang positif.

Tingkat signifikansi koefisien korelasi adalah 0.083. Oleh karena probabilitas jauh di atas 0.05, maka korelasi antara bahasa kasih yang ditunjukkan oleh orang tua dengan prestasi anak autis tidak nyata. Artinya korelasi bahasa kasih dan prestasi tidak dapat disimpulkan secara pasti.

Berdasarkan isian angket diperoleh data bahwa semakin banyak bahasa kasih yang ditunjukkan oleh orang tua maka semakin besar pula prestasi yang ditunjukkan oleh anak autis. Adapun bahasa kasih yang ditunjukkan oleh orang tua diantaranya: orang tua selalu mengatakan papa/mama sayang kamu kepada anak autis, selalu memberikan pelukan dan belaian kepada anak, memberikan pujian ketika anak bisa melakukan sesuatu yang disuruh orang tua,dan memiliki waktu bermain bersama dengan anak. Bahasa kasih yang ditunjukkan oleh orang tua tersebut akan meningkatkan prestasi anak autis, seperti: sudah tidak kaku dan tegang, tidak lagi mengepal tangan dan menegangkan kaki secara berlebihan, bereaksi terhadap kata dan suara, bisa bermain bersama dengan anak-anak lainnya, memiliki perbendaharaan kata yang cukup, tidak pasif dan pendiam, tidak suka lagi membeo dan mengeluarkan suara aneh dan sudah bisa mengucapkan kata yang ada artinya.

\section{Table Persentasi}

Model Summary
\begin{tabular}{|l|l|l|l|l|}
\hline Model & $\mathrm{R}$ & R Square & Adjusted R Square & $\begin{array}{l}\text { Std. Error of } \\
\text { the Estimate }\end{array}$ \\
\hline 1 & $.285^{\mathrm{a}}$ & .081 & .042 & 5.514 \\
\hline
\end{tabular}
a. Predictors: (Constant), Bahasa Kasih
b. Dependent Variable: Prestasi

Angka R square adalah 0.081 dikali 100\% menjadi 8\%. Hal ini berarti $8 \%$ variabel prestasi ditentukan oleh variabel bahasa kasih yang 
ditunjukkan oleh orang tua. Sisanya yaitu 92\% ditentukan oleh faktor lain. Walaupun bahasa kasih yang ditunjukkan oleh orang tua hanya berpengaruh sebanyak $8 \%$ terhadap prestasi anak autis, tetapi anak autis tetap harus membutuhkan bahasa kasih dari orang tua mereka. Sangat disarankan bagi orang tua agar selalu menunjukkan bahasa kasih kepada anaknya yang menderita autis. Karena mungkin tanpa disadari oleh orang tua, hal ini akan memberikan perubahan yang signifikan terhadap perkembangan anak autis, terutama kepada prestasi yang akan dicapai oleh anak autis itu sendiri.

Kita bisa melihat contoh yang nyata, yaitu pada orang tua dari Oscar Yuda Rompas.Ketika mengetahui anaknya menyandang autis. Berikut adalah kesaksiannya:

Sewaktu umur Oscar Yura Dompas memasuki usia tiga tahun, ayahnya baru menyadari ada yang berbeda pada diri Oscar. "Ia asyik sendiri. Berbeda dengan adiknya, Nikita yang suka jalan-jalan dan kalau dipanggil pun menengok," cerita Jeffrey. Jeffrey dan istri memeriksakan Oscar ke dokter. Waktu itu masih tahun 1980-an, gangguan autis belum dikenal. "Dunia psikologi belum memahami autis. Sedikit sekali ahli yang memahami autis. Jadi diagnose awal adalah Minimal Brain Damaged".

Mengetahui diagnose tersebut, Jeffrey dan istri tidak saling menyalahkan. Mereka sadar, Oscar adalah anugerah dari Tuhan. "Kita berkewajiban merawatnya dengan penuh kasih sayang karena anak itu adalah pemberian Tuhan". Jeffrey dan istri hanya bisa pasrah kepada Tuhan dan berusaha memberikan yang terbaik untuk Oscar. Mereka yakin bila berserah dan berusaha, Tuhan akan memberikan yang terbaik. "tidak ada beban berat yang kita pikul kalau beban itu dari Allah sendiri. Kami yakin bisa hadapi ini dengan ringan".

Jeffrey dan istri sama sekali tidak malu memiliki anak penyandang autis. "saya enggak malu. Kenapa harus malu?" tandasnya. Jeffrey sangat menyayangkan bila ada orang tua yang malu karena memiliki anak yang menyandang autis. "kebanyakan pada kasus seperti ini para orang tua saling menyalahkan, bahkan ada yang sampai bercerai".

Diakui Jeffrey, tidak mudah merawat Oscar. Anak-anak autis ,memiliki keterbatasan menyampaikan pendapat. "kalau anak normal menangis, dia masih bisa mengatakan alasannya. Kalau Oscar, tidak bisa seperti itu," ujar ayahnya. Saat Oscar mengalami letupan emosi yang agresif tak terkendali, ia akan meronta-ronta. Di saat seperti itu, Jeffrey berusaha memeluknya erat-erat dan mencoba berkomunikasi secara batin. "saat memeluk dia, saya katakan padanya, papa cinta kamu, mama sayang kamu, adik sayang sama 
kamu." Ternyata komunikasi tersebut mampu menenangkan Oscar, bahkan ia sampai tertidur di pelukan Jeffrey.

Jeffrey dan istri juga terus berusaha melatih motorik Oscar. "saya ajarkan dia Doa Rosario. Doa Rosario itu kan mengulang, dan anak autis punya kebiasaan mengulang-ulang. Jadi kami ajarkan doa dengan gerakan, akhirnya motoriknya jadi bagus," jelas istrinya.

Jeffrey bersama istri dan anak-anaknya turut terlibat membantu Oscar berinteraksi dengan orang lain. "awalnya memang sulit. Lalu kami pakai cara dengan contoh-contoh. Butuh kesabaran dan perhatian lebih", jelas Jeffrey.

Selain itu, Jeffrey mencoba melatih kepekaan hatinya. Dalam merawat dan mendidik Oscar, Jeffrey menggunakan naluri atau instingnya. "kadang-kadang dokter bilang demikian, tetapi insting kami tidak demikian. Jadi kami lebih memakai insting kami, karena kami orangtuanya sehingga kami lebih memahami anak kami."

Jeffrey memasukkan Oscar ke pendidikan formal. "Oscar sekolah di sekolah biasa. Sebelumnya kami bicara lebih dulu kepada gurunya mengenai kondisi Oscar." Oscar akhirnya bisa menempuh pendidikan formal sampai selesai. Bahkan ia mampu menyelesaikan pendidikan S1 Sastra Inggris di UNIKA Atma Jaya. Saat kelas 2 SMA, Oscar studi ke Australia. "itu pendidikan umum tetapi privat. Ia diajarkan untuk bisa menjadi pribadi yang mandiri, memiliki misi, dan memiliki nilai-nilai Katolik." Sepulang dari sana, banyak sekali perubahan yang dialami oleh Oscar. "cara berpikirnya berubah, menjadi mandiri. Sudah menelurkan sebuah buku, Autistic Journey,"kata ayahnya. ${ }^{11}$

Kesaksian tersebut diatas memberikan pelajaran bagi kita bahwa apabila kita tekun dan tidak pernah berhenti untuk berusaha, maka kita akan mendapatkan sesuatu hal yang tidak pernah kita pernah bayangkan dan pikirkan. Penyandang autis bukanlah gumpalan benang kusut dalam mesin kehidupan. Apabila diberikan kasih sayang secara utuh, maka benang kusut itu akan menjadi pintalan benang yang siap dirajut bagi kain bermotif keindahan dan berwarna keceriaan. Jeffrey yang tidak pernah lelah untuk berusaha demi kesembuhan anaknya, Oscar, kini bisa tersenyum bahagia melihat hasil dari perjuangannya selama ini. Prestasi yang Oscar raih begitu sangat luar biasa. Bahasa kasih berupa pelukan, kata-kata penegasan, waktu yang berkualitas, layanan, dan perhatian yang selalu orangtua tunjukkan kepada anaknya, bisa membawa anaknya meraih prestasi yang sangat gemilang. Ketika anak mengalami letupan emosi yang tak terkendali, ia akan meronta-ronta, tetapi pada saat orangtuanya memeluknya erat-erat dan berkata

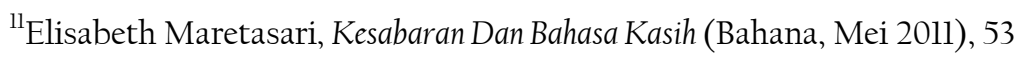


padanya: "papa cinta kamu, mama sayang kamu, adik sayang sama kamu." Maka anaknya menjadi tenang bahkan ia sampai tertidur.

Dengan latihan yang dilakukan secara teratur dan terus menerus, akhirnya motorik anak menjadi bagus. Anaknya juga sudah bisa berinteraksi dengan orang lain. Prestasi yang luar biasa lainnya adalah anak bisa menempuh pendidikan formal sampai selesai bahkan menulis sebuah buku berjudul "Autistic Journey."

\section{Tabel Persamaan Regresi}

\begin{tabular}{|ll|l|}
\hline \multirow{2}{*}{ Model } & Unstandardized Coefficients \\
\cline { 2 - 3 } & B \\
\hline 1 & (Constant) & 19.283 \\
Bahasa Kasih & 1.262 \\
\hline
\end{tabular}

Tabel di atas mengambarkan persamaan regresi

$\mathrm{Y}=19.283+1.262 \mathrm{X}$

Di mana:

$\mathrm{Y}=$ Prestasi

$\mathrm{X}=$ bahasa kasih

Konstanta sebesar 19.283 menyatakan bahwa jika tidak ada bahasa kasih maka prestasi anak autis adalah 19.283. koefisien regresi sebesar 1.262 menyatakan bahwa setiap penambahan 1 skor penerimaan orang tua akan meningkatkan prestasi sebesar 1.262. 


\section{Gambar Hubungan Bahasa Kasih Dengan Prestasi Scatterplot}

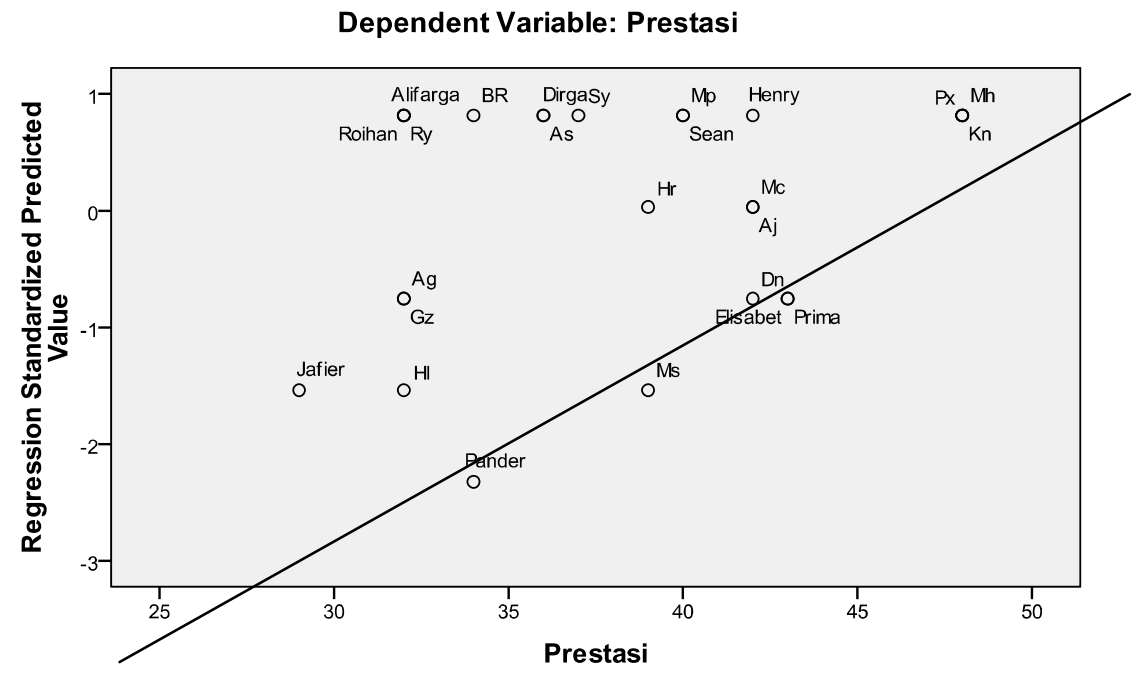

Terlihat bahwa sebaran data membentuk arah ke kanan atas, dan jika ditarik garis lurus akan didapat slope yang positif. Hal ini berarti ada hubungan yang positif antara prestasi dan bahasa kasih.

\section{Kesimpulan}

\section{PENUTUP}

Pertama, Penerimaan orang tua berpengaruh terhadap prestasi anak autis. Tingginya prestasi anak autis ditentukan oleh penerimaan orang tua, seperti: menerima kenyataan memiliki anak autis, dapat menerima keberadaan anaknya yang autis, melakukan penanganan terhadap anak autis sesuai kebutuhannya, serta tidak merasa rendah diri terhadap keberadaan anaknya. Maka prestasi anak autis yang meningkat, antara lain adalah: anak autis menjadi tidak terlalu sensitif, bisa melakukan kontak mata dan senyum secara sosial, tidak kaku lagi terhadap orang lain, sudah tidak berteriak- teriak dan tidak membeo, tidak gampang marah (memiliki emosi yang stabil), tidak mudah menyakiti diri sendiri, sudah bisa bermain dengan teman-temannya

Kedua, bahasa kasih yang ditunjukkan oleh orang tua berpengaruh terhadap prestasi anak autis. Tingginya prestasi anak autis ditentukan oleh bahasa kasih yang ditunjukkan oleh orang tua seperti: orang tua selalu mengatakan kepada anaknya yang autis: "papa/mama sayang kamu", anak diberikan pujian yang tulus, orang tua memiliki waktu yang khusus bersama dengan anak dan memberikan hadiah kepada anak. 
Maka prestasi anak autis yang meningkat, antara lain adalah sudah tidak kaku dan tegang, tidak lagi mengepal tangan dan menegangkan kaki secara berlebihan, bereaksi terhadap kata dan suara, bisa bermain bersama dengan anak-anak lainnya, memiliki perbendaharaan kata yang cukup, tidak pasif dan pendiam, tidak suka lagi membeo dan mengeluarkan suara aneh dan sudah bisa mengucapkan kata yang ada artinya.

\section{Saran-Saran}

Adapun saran-saran dari penulis sehubungan dengan dampak keterbukaan orang tua terhadap prestasi anak autis yaitu:

Pertama, tindakan awal yang perlu dilakukan oleh para orang tua anak autis adalah orang tua perlu teliti dalam mengamati berbagai gejala yang nampak pada diri anak yang autis. Ketelitian orang tua dalam mengamati berbagai gejala tersebut, akan menjadi bahan acuan bagi orang tua dalam mengambil keputusan yang tepat dalam memberikan penanganan secara dini kepada anaknya yang autis. Kedua, penanganan yang diberikan orang tua kepada anaknya yang autis sebaiknya bersifat terpadu dan menyeluruh yang mencakup aspek fisik dan psikis atau jasmani dan rohani. Pemberian pendidikan dan latihan secara intensif tanpa dibarengi dengan upaya memperbaiki keseimbangan metabolisme atau perbaikan kondisi fisik pada diri anak yang autis, maka akan memberikan hasil yang kurang optimal. Sebaliknya, jika para orang tua hanya menggantungkan harapan pada obat-obatan atau control makanan tanpa ada usaha pemberian pendidikan dan latihan yang intensif, kontinu, dan konsisten kepada anak yang autis, tentu saja hasilnya juga kurang optimal. Ketiga, para orang tua tidak boleh lupa bahwa meskipun anaknya menderita autis, namun anaknya yang autis tersebut terus mengalami perubahan atau perkembangan. Karena itu, para orang tua anak autis harus juga selalu berkembang dengan cara para orang tua harus selalu berusaha dan belajar terus menerus untuk mempelajari berbagai hal yang berhubungan dengan semua aspek kehidupan anak yang autis. Keempat, dalam melayani kebutuhan anak autis, baik oleh orang tua, guru, keluarga, terapis, pembantu rumah tangga, dan pihak lain yang menaruh minat dan peduli terhadap anak autis, dibutuhkan kesabaran, ketekunan, keikhlasan, dan sikap mau menerima keberadaan anak autis apa adanya. Selain itu dibutuhkan kerjasama yang baik dari semua pihak-pihak tersebut untuk menghindari rasa bosan dalam melayani kebutuhan anak autis tersebut. Kelima, guru perlu memperhatikan kelemahan dan kekuatan anak sebagai basis dalam menyusun dan menerapkan pendidikan untuk anak autistik. Guru perlu memberikan latihan terstruktur yang memperkecil kesempatan anak untuk melepaskan diri dari teman-temannya dan guru 
segera bertindak bila melihat anak melakukan aktivitas sendiri. Anak perlu diikutsertakan dalam proses penyusunan program pelatihan terstruktur ini dengan tujuan agar anak dapat mengatur sendiri pikiran dan tindakannya agar anak dapat bekerja atas dasar kemampuan sendiri (mandiri).

Keenam, guru harus berusaha untuk membangkitkan rasa percaya diri pada anak dan membantu orang tua untuk mengerti dan mempraktekkan teknik-teknik perilaku yang diajarkan bersama-sama dengan anak autis agar meningkatkan persepsi orang tua, sehingga orang tua dapat membantu dengan efektif dan mengontrol perilaku anak mereka.

Ketujuh, Gereja hendaknya turut mengambil peran, dalam hal ini anggota gereja saling menopang, dan membantu serta peduli kepada orang tua yang memiliki anak autis. Kepedulian sederhana seperti menyapa, memberi tumpangan, memperhatikan perkembangan anakanak yang mengalami autis, meskipun bukan saudara, tetapi kita menunjukkan kasih kristiani yang sejati. Anak dengan diagnosa autisme bukan berarti tidak bisa menangkap hal-hal yang diajarkan. Oleh karena itu tidak ada alasan menunda memperkenalkan Yesus kepada anak. sehingga anak bisa memahami bahwa walaupun ada kekurangan dalam dirinya, namun Tuhan memiliki rencana besar atas hidupnya termasuk cita-citanya kelak.

\section{KEPUSTAKAAN}

Brand, R. Kent dan Williams, Charles D. Delapan Masalah Utama Orang Tua Dan Anak, Cara Menanggulanginya. Jakarta: BPK Gunung Mulia, 1991

Drescher, M. John. Tujuh Kebutuhan Anak. Jakarta: BPK Gunung Mulia, 1992

Gunarsa, Yulia dan Singgih. Psikologi Perkembangan Anak Dan Remaja. Jakarta: Gunung Mulia, 2010

Hadis, Abdul. Pendidikan Anak Berkebutuhan Khusus Autistik. Bandung: Alfabeta, 2006

Handoyo, Y. Petunjuk Praktis dan Pedoman Materi untuk Mengajar Anak Normal, Autis dan Perilaku lain. Jakarta: PT. Bhuana Ilmu Populer, 2006

Maulana, Mirza. Anak Autis : Mendidik Anak Autis dan Gangguan Mental Lain Menuju Anak Cerdas dan Sehat. Jogjakarta: Kata Hati, 2007

Rohman, Wahyu. Prof. Hembing Telah Sembuhkan Anakku dari Autism. Jakarta, 2002. 